\title{
A Study of Practical Training Module for Application-oriented Undergraduate Tourism Management Based on Student Satisfaction: A Case Study of Tianhua College of Shanghai Normal University
}

\author{
Jiaxiu Guo \\ School of management \\ Shanghai Normal Unversity Tianhua College \\ Shanghai, China \\ 835426910@qq.com
}

\author{
$\mathrm{Na} \mathrm{Hu}$ \\ School of management \\ Shanghai Normal University Tianhua College \\ Shanghai, China \\ 1750179581@qq.com
}

\begin{abstract}
Practical teaching plays a key role in training system for tourism professionals. This paper takes the whole student of Tourism Management of Tianhua College of Shanghai Normal University as the research object, and adopts a combination of questionnaire survey and interview method to conduct a research from the aspects of training objectives, timing, content arrangement, training gains, teacher arrangement, and assessment methods. The problems are low utilization of training bases in schools, insufficient depth of school-enterprise cooperation, a lacking of "practical" teachers, and a single method of practical training assessment. The recommendations for optimizing training like standardizing the construction of training bases, improving the use of campus training bases, strengthening school-enterprise cooperation, establishing "dualqualified" and "double-structured" teaching teams, and innovating assessment methods are further proposed, which aims to promote our school tourism management professional training in the direction of a more optimized development.
\end{abstract}

Keywords-training; questionnaire survey; training arrangement; assessment

\section{INTRODUCTION}

In 2013, the General Office of the State Council released the National Tourism and Leisure Program (2013-2020) to the public and proposed the development goals of the national tourism and leisure development: by 2020, the system of paid leave for employees will be basically implemented, the level of leisure tourism consumption of urban and rural residents will increase substantially, the leisure quality of the national people will be significantly improved, and the modern national tourism leisure system that is compatible with the well-to-do society will be basically completed. With the improvement and completion of the national tourism and leisure system, the tourism industry will surely develop rapidly, and the demand for relevant professionals will continue to increase, especially for students with innovative and entrepreneurial skills. This trend puts forward higher requirements for the practical training courses of the general colleges and universities in tourism management [1].

As a tourism management major serving the local economy, cultivating applied talents is the goal of education. The most important orientation of the local colleges and universities is to face the frontline of the grassroots, and to cultivate applied talents with a complete knowledge system and a certain level of learning ability and application ability. Therefore, the position of practical teaching in the personnel training system is particularly important. The practice teaching of tourism management should adhere to the theory and practice, and establish a multi-level, multi-dimensional, comprehensive practical teaching system for tourism management, which requires more in-depth cooperation between schools and enterprises to improve their professional comprehensive ability [2].

\section{InVEstigation on Practical TEAching OF TOURISM MANAGEMENT}

Practical teaching is a core part of the tourism management teaching system. There are currently 6 on-campus training courses for the tourism management of our university, which are as follows: 
TABLE I. INTRODUCTION TO TRAINING IN TOURISM MANAGEMENT

\begin{tabular}{|c|c|c|c|c|c|}
\hline Training name & Semester & $\begin{array}{l}\text { Training contents } \\
\end{array}$ & Location & Time & Assessment \\
\hline $\begin{array}{l}\text { Simulation of tour } \\
\text { guide training }\end{array}$ & Semester 3 & $\begin{array}{l}\text { 1. Master the overview of People's Square, the Bund, } \\
\text { Oriental Pearl, Yuyuan Garden and Longhua Temple Tourist } \\
\text { Area; } 2 \text {. Grasp the geographical location, historical evolution, } \\
\text { and scenic features of the five scenic spots within the area. }\end{array}$ & $\begin{array}{l}\text { Shanghai's five } \\
\text { major scenic spots }\end{array}$ & $\begin{array}{l}\text { Two } \\
\text { weeks }\end{array}$ & $\begin{array}{l}\text { Interview simulation } \\
\text { assessment + training } \\
\text { summary }\end{array}$ \\
\hline $\begin{array}{l}\text { Guide training in } \\
\text { tourist attractions }\end{array}$ & Semester 4 & $\begin{array}{l}\text { 1. Design a reasonable route and schedule; } \\
\text { 2. Write welcoming speeches and explain words along the } \\
\text { way, and explain on the wagon; } \\
\text { 3. Compose a farewell message and send greetings on the } \\
\text { way home. } 4 \text {. Conduct tourguides at the scenic spot to } \\
\text { provide satisfactory services for tourists. }\end{array}$ & Anhui Huangshan & $\begin{array}{l}\text { One } \\
\text { week }\end{array}$ & $\begin{array}{l}\text { Welcome speech } \\
\text { Farewell speech; } \\
\text { Scenic guide words; } \\
\text { On-site explanation; } \\
\text { Internship summary. }\end{array}$ \\
\hline $\begin{array}{l}\text { Tourism business } \\
\text { training }\end{array}$ & Semester 5 & $\begin{array}{l}\text { 1. Guided tours independently; } \\
\text { 2. Understand the business status of the tourism industry } \\
\text { through business visits, lectures and other activities. }\end{array}$ & $\begin{array}{l}\text { Jiangsu, Zhejiang } \\
\text { and Shanghai scenic } \\
\text { spots and Ctrip }\end{array}$ & $\begin{array}{l}\text { One } \\
\text { week }\end{array}$ & $\begin{array}{l}\text { Summary of practical } \\
\text { training }\end{array}$ \\
\hline $\begin{array}{l}\text { Tourism project } \\
\text { market research }\end{array}$ & Semester 6 & $\begin{array}{l}\text { 1. Understand the operation and construction of tourist } \\
\text { attractions and destinations through market research; } 2 \text {. } \\
\text { Grasp the tourist satisfaction of tourist attractions; } \\
\text { 3. Understand the behavior of tourists; } \\
\text { 4. Understand the construction of smart scenic spots. }\end{array}$ & Xi'an or Beijing & $\begin{array}{l}\text { One } \\
\text { week }\end{array}$ & $\begin{array}{l}\text { Research plan; survey } \\
\text { questionnaire; research } \\
\text { report. }\end{array}$ \\
\hline $\begin{array}{l}\text { Tourism } \\
\text { information } \\
\text { management } \\
\text { software I } \\
\end{array}$ & Semester 6 & $\begin{array}{l}\text { 1. Learn the establishment of guest history files; } \\
\text { 2. Learn hotel reservations, check-in, consumption credits; } \\
\text { 3. Learn the guest checkout, nightly review, accounts } \\
\text { receivable management, and team booking. }\end{array}$ & $\begin{array}{l}\text { On-campus training } \\
\text { room }\end{array}$ & $\begin{array}{l}\text { One } \\
\text { week }\end{array}$ & $\begin{array}{l}\text { Software operation } \\
\text { process assessment; } \\
\text { training summary }\end{array}$ \\
\hline $\begin{array}{l}\text { Tourism } \\
\text { Information } \\
\text { Management } \\
\text { Software II } \\
\end{array}$ & Semester 7 & $\begin{array}{l}\text { 1. Master the operation process of travel agency business } \\
\text { through the system simulation of the actual operation of } \\
\text { travel agencies; } 2 \text {. Master the basic skills of managing travel } \\
\text { agency business. }\end{array}$ & $\begin{array}{l}\text { On-campus training } \\
\text { room }\end{array}$ & $\begin{array}{l}\text { One } \\
\text { week }\end{array}$ & $\begin{array}{l}\text { Software operation } \\
\text { process assessment; } \\
\text { training summary }\end{array}$ \\
\hline
\end{tabular}

Through questionnaires and interviews and other research methods, the author conducted a questionnaire survey of the tourism management students of Tianhua University of Shanghai Normal University. A total of 245 questionnaires were issued and 245 valid questionnaires were retrieved. $100 \%$ of the surveys were valid. The survey data was analyzed by SPSS 18.0. Questionnaire surveys focused on issues related to the practical teaching content of tourism management, including the clarity of training objectives, the timing of students' training, the arrangement of training content, the harvest of training, the arrangement of teachers for practical training, and the training assessment methods.

\section{TRAINING SATISFACTION ANALYSIS}

\section{A. Understanding of the purpose and significance of training}

For surveys on whether or not to understand the six major training objectives, the three grades of tourism management have given higher satisfaction and their satisfaction has exceeded 93\%, which indicates that when mobilizing and arranging work in the early stage of training, the purpose and significance of the training are fully explained, and students have fully understanding of the purpose of training.

\section{B. Analysis of timeliness for training schedule}

The time arrangement of training is mainly shown in two aspects, first of all, whether the time series of the 6 practical training is reasonable. From the students' questionnaire, the satisfaction is $92.96 \%$. Firstly, a simulated tour guide training was set up to assist the tour guide qualification examination. On this basis, guided tour guides for tourist attractions are conducive to improving the students' ability to integrate theory with practice. Afterwards, the tourism business training requires the students to conduct training guided by groups on their own to learn more about the operation of tourism companies, which increased the actual operational ability of students. The final survey of the tourism project market is related to the later graduation thesis, prompting the students to learn how to solve the problems in the tourism by using research methods. The four practices are gradual in the cultivation of the students. This is in line with the students' cognitive laws. As a result, it is much more popular with students.

Secondly, the time is reasonable, which is reflected in the length of time and the timing of the semester. From the students' questionnaires, more than $91.43 \%$ of students in the freshman and junior year students are satisfied with the training schedule.

\section{Analysis of satisfaction with training content}

For the satisfaction of training content, there is a big disagreement. The students expressed the most satisfactory arrangement for the simulated tour guide training, because the direct help of the tour guide qualification examination is most clear, and its satisfaction is over 95\%. For the tourism business training, all the students think that the project arrangement is reasonable, but in the process of specific operations, the objective reasons lead to low satisfaction, and $67.14 \%$ of the students think that the opportunities for bringing groups are too few to exercise practice skills. It is concluded that students have higher willingness to take a tour guide, but that schools have fewer opportunities to meet their needs. For the module content of tour guides for tourist attractions, the satisfaction of students is $92.10 \%$. This training mainly exercises students' ability to explain. For the content of the tourism project market research, students also showed a 
high degree of satisfaction, which is $90.78 \%$. Through market research, students have mastered the basic methods of market research, and have combined the learning and practice of ordinary books, achieving good results.

For tourism information management software I, the main learning content is related to the operation of the hotel's front room reservation, which is the basic content of the hotel work, however, due to the low degree of association with the students' professional orientation (outbound leader and travel e-commerce), students gave lower satisfaction. For tourism information management software II, the main learning content is the operation of the basic travel agency process since it has a high degree of relevance with the professional direction. The final satisfaction is high.

\section{Analysis of teacher satisfaction for practical training}

In the process of designing the questionnaire, the problem of teacher satisfaction was only set up for tourism information management software I and II, mainly due to the relatively small influence of the first four training instructors on the students' training effect and relatively big influence of the teachers' teaching effectiveness of tourism information management software I and II on the results. Through student questionnaires, it was found that teachers lacked corresponding industry experience. Among them, the percentage of teachers who can't fully explain the application of the software is $53.28 \%$, and the percentage of teachers who lack professional guidance and industry education is $30.21 \%$. Therefore, for the training of informatization software in two on-campus training rooms, the allocation of teachers with extensive industry experience is a key issue to be considered.

\section{E. Analysis of satisfaction of training assessment methods}

Through the analysis of the questionnaire, it is found that the students have the lowest satisfaction with the assessment method of the entire training, and the training assessment methods include the group work and the training summary. The students participating in the survey all said that free riders would appear in group work. Some students did not assume group tasks but enjoyed group results, which affected the enthusiasm of other students to some extent. For the training summary, different assessment methods can be used for different training purposes. Different assessment methods for different projects are the key issues that must be considered in the optimization of training programs.

\section{F. Analysis of training gains}

An interesting phenomenon emerged from the analysis of training gains. Students' satisfaction with simulated tour guides, tour guides for tourist attractions, tourism training, and tourism project market surveys is much higher than tourism information management software I and tourism information management software II. The survey found that $39.44 \%$ of the students indicated that they gained little from tourism information management software I and they did not know the purpose of it. However, only 36.62\% of the students believed that they have gained another skill in addition to their major and it will broaden their employment options. One of the reasons is that the system adopted for the tourism information management software is sinfonia, which cannot keep up with the trend of the times with its obsolete content and knowledge. For the tourism information management software II, $42.25 \%$ of the students thought that they had a basic understanding of the travel business process through software operation and teacher's explanation and they can operate the general process now. 30.99\% of the students thought that they gained little.

Because tourism information management software I and II are simulations of business processes, they cannot represent the real business conditions of the company; this is an important reason why students feel that they gained little. This shows that although the training room in the school can take part in teaching functions, due to its virtual nature, it's difficult for students to understand the real situation of the enterprise. This requires schools to continue to vigorously develop school-enterprise cooperation and provide students with a real working environment.

\section{THE MAIN PROBLEMS IN THE TRAINING SYSTEM}

\section{A. Insufficient construction and usage rate of campus training base}

In the two parts of the training base campus and off campus, the following problems exist in our school: The oncampus training base is not perfect. Currently, the training room jointly built with the Golden Palm Network Technology Co., Ltd. has been established, but the utilization rate is low and some functions are still being optimized and only juniors can get involved. In addition, the integration of professional courses and training rooms is low.

\section{B. Insufficient cooperation with off-campus tourism enterprise units}

Although the major has established a large number of offcampus school-enterprise cooperation units, however, there is a lack of deep school-enterprise cooperation units. Basically, the content of cooperation is that the student went to the unit to do an internship after graduation. The unit had not been effectively integrated into the previous teaching and training, and students had relatively little knowledge of the enterprise. At the same time, enterprises are less likely to provide students with internships given their operating costs.

\section{Lack of "practical" teachers}

Most of the professional teachers go directly to the school after graduating from school and have not worked in travel agencies and scenic spots, hotels, travel companies, etc. Therefore, the relevant practical experience is very scarce, and it is difficult to give practical examples and scientific management methods in the classroom and training management.

\section{Single training assessment}

The assessment at the end of training is an important part of training for tourism students. At present, most of our tourism professional training only evaluates and comments students in the form of internship summary and internship reports. In the survey questionnaire and the author's interview, 
a considerable number of students reported that such an assessment approach was in a form that was too monotonous and did not really play a role. It was difficult to judge whether the students' practical skills during the entire training process had been improved.

\section{TRAINING IMPROVEMENT STRATEGY}

\section{A. Standardize the construction of training bases and improve the usage rate of campus training bases}

Training bases inside and outside of campus are important teaching sites for students to expand their horizons, cultivate professional awareness, innovative abilities and hands-on skills, and master professional skills. To do well in the training base is the premise and foundation for training qualified professionals in tourism management. [3] The on-campus training base is an important place for practical training. The construction requires a high degree of simulation to meet the needs of students' practical training. Therefore, we should strictly divide and standardize the construction and put some chapters of relevant courses in the on-campus training room. At the same time, we also encourage students to put innovative and entrepreneurial projects in the training room to increase the usage rate of the training base.

\section{B. Strengthen school-enterprise cooperation}

Schools should cooperate with tourism enterprise units to establish relatively stable relevant training bases. Due to the limited admission of travel agencies, school can establish a friendly and cooperative relationship with one or more travel agencies. When selecting a tourism enterprise unit, a tourism enterprise that is highly professional with standard operation is in advanced management level in the industry should be selected as a training base. Moreover, when a school establishes a cooperative relationship with a tourism enterprise, it should sign a labor contract to clarify the obligations and responsibilities of both parties to protect the safety and interests of students. Schools should continue to provide students with more learning platforms, so that they can find their own inadequacies in practice, and constantly improve themselves, and ultimately meet the quality requirements of post employees.

\section{Establish a "double-qualified" and "double-structured" teaching team}

We should create a "dual-qualified" team of teachers. In the context of the new era, the tourism management professional teachers must possess both professional knowledge and practical ability. Otherwise, they will not be able to perform the tasks of the tourism management professional teachers. Therefore, schools should cultivate a group of tourism teachers that understand both theory and practice, conduct vocational training for on-the-job tourism professional teachers, allow full-time teachers to go on tour companies and enable teachers to know the development of tourism industry at close quarters, get familiar with and familiar with the skills of the first-line jobs in the tourism industry, and understand the operating mechanisms and specific operational skills of the tourism companies.

On the other hand, the school can hire staff from the tourism industry with practical experience as part-time teachers. The teaching of $\mathrm{AB}$ angle by full-time teachers and part-time teachers can not only supplement the short board of the lack of theory of part-time teachers, but also serve as a good way of learning for full-time teachers.

\section{Innovate assessment method}

It is necessary to establish a complete set of assessment system, and to examine the accuracy and standardization of the students' operating skills and service procedures, as well as the students' professional quality, professional consciousness and professional ethics in the process of skill operation and management service, combined with the methods of process assessment and result assessment [4]. The form of a single practical training summary and practical training report should be changed. After the end of the training, the students' subjective initiative and innovation assessment method should be fully played. For example, we can organize homestay design contests, travel marketing promotion strategies, training contest competitions, and experience exchange sharing sessions after training, practice photography skills competitions, and best training moment captures, etc.

\section{CONCLUSIONS}

Through the investigation of all the students of the tourism management, it is known that the practical training setting of the major is relatively reasonable, which can be reflected not only from the consistency of the content before and after, but also the degree of convergence with the professional curriculum. However, in the specific operation process, due to the limitation of the conditions, some trainings fail to reach the established goals. Therefore, continuous revision and improvement of practical training programs through investigation and observation is an important way to optimize training programs.

\section{REFERENCES}

[1] Zhan Yanjie. Analysis on the Status Quo and Countermeasures of Practical Training Teaching in University Tourism Management [J].Bridge of Century.2013.1.

[2] Lv Qian. Research on the Three-dimensional Teaching Practice of Universities based on the Concept of Collaborative Innovation-Taking Tourism Management as an Example [J].Focus Education.2015.12.

[3] Zeng Chunxia. The Current Situation and Countermeasures of the Practical Training of Tourism Management Professionals [J]. Commercial Economy. 2007.10.

[4] Pan Hong. Exploration of Undergraduate Tourism Management Professional Training Module-oriented Teaching Based on Application Ability Cultivation [J]. Journal of Changchun Education Institute. 2013. 12. 